\title{
MODEL PEMBELAJARAN THINK PAIR SHARE (TPS) DIPADU MODEL SURVEY QUESTION READ RECITE REVIEW (SQ3R) DALAM MENINGKATKAN HASIL BELAJAR PESERTA DIDIK DI KELAS IX SMP NEGERI 6 KOTA TERNATE
}

\author{
Zakiah Syahruddin $^{1}$, Chumidach Roini. ${ }^{2}$, Arini Z. Nasichah ${ }^{3}$ \\ ${ }^{123}$ Magister Pendidikan Biologi Universitas Khairun Ternate \\ zakiahsyahruddin@gmail.com,
}

\begin{abstract}
Abstrak
Penelitian ini bertujuan untuk mengetahui perpaduan model Think Pair Share (TPS) dengan Survey Question Read Recite Review (SQ3R) untuk meningkatkan hasil belajar kognitif peserta didik. Metode penelitian yang digunakan adalah Quasi Eksperimen. Penelitian ini dilakukan di SMP Negeri 6 Kota Ternate dengan sampel peserta didik berjumlah 64 siswa, dengan kelas IX-6 menggunakan model TPS, kelas IX-3 menggunakan model pembelajaran SQ3R, sedangkan kelas IX-5 penggunakan model pembelajaran perpaduan model TPS dengan SQ3R, pada semester Ganjil tahun pelajaran 2018/2019. Pengumpulan data dilakukan dengan pretest dan postest. Analisis data menggunakan uji ANOVA. Hasil penelitian menunjukan bahwa Perpaduan model pembelajaran TPS dan SQ3R dapat meningkatkan hasil belajar peserta didik. Hasil belajar peserta didik menggunakan perpaduan model pembelajaran Think Pair Share dengan Survey Question Read Recite Review rata-rata skornya 79,32, sedangkan rata-rata skor hasil belajar peserta didik dengan menggunakan model Survey Question Read Recite Review sebesar 76,27 dan dengan menggunakan model Think Pair Share sebesar 74,60. Pada pengujian hipotesis bahwa model pembelajaran menunjukan nilai signifikan $0,000<0,05$ yang berarti hipotesis diterima hal ini berarti bahwa hasil belajar peserta didik yang menggunakan perpaduan model Think Pair Share dengan Survey Question Read Recite Review lebih baik dari pada model pembelajaran Think Pair Share maupun Survey Question Read Recite Review.
\end{abstract}

Kata kunci: model pembelajaran, TPS, SQ3R dan hasil belajar.

\section{PENDAHULUAN}

Pendidikan merupakan interaksi antara guru dengan siswa untuk mencapai tujuan pendidikan. Guru sebagai tenaga pendidik harus dapat mengembangkan potensi peserta didik secara optimal dengan kemampuan untuk berkreasi, mandiri, bertanggung jawab, dan dapat memecahkan masalah-masalah yang dihadapi sehingga nantinya dapat melaksanakan fungsinya sebagai pendidik dalam pembelajaran di kelas sebaiknya tidak hanya di dominasi oleh guru saja akan tetapi harus siswa yang lebih aktif karena siswalah yang harus belajar bukan guru. Pembelajaran berlangsung secara interaktif, inspiratif, menyenangkan, menantang, serta dapat memotivasi siswa sehingga mencapai kompetensi yang diinginkan (Widyantini, 2008). Kemampuan guru dalam mengembangkan model 
pembelajaran dapat meningkatkan intensitas keterlibatan siswa secara efektif guna mencapai keberhasilan proses pembelajaran. Penggunaan model pembelajaran yang tepat dapat mendorong tumbuhnya rasa senang siswa terhadap pelajaran, menumbuhkan dan meningkatkan motivasi belajar (Anmurahman, 2012).

Pembelajaran kooperatif merupakan pembelajaran yang di dalamnya siswa bekerja bersama untuk mencapai tujuan khusus atau menyelelesaikan masalah. Dalam pembelajaran kooperatif siswa diberi kesempatan untuk membicarakan pengamatan mereka, ide-ide mereka, dan teori-teori mereka dalam rangka memahami pelajaran mereka. Selain itu, dalam pembelajaran kelompok diciptakan suasana kebersamaan dan saling menghargai antara siswa dalam rangka mencapai tujuan pembelajaran. Pembelajaran kooperatif dapat dioptimalkan dalam rangka meredam sensitivitas dan egoisme etnik secara dini di sekolah-sekolah.

Pembelajaran Think Pair Share (TPS) merupakan pembelajaran kelompok dimana siswa diberi kesempatan untuk berfikir mandiri dan saling membantu dengan teman yang lain. Hal tersebut di atas diperkuat dengan penelitian tentang model Think Pair Share (TPS )yang pernah dilakukan oleh Kitaoka (2013), yang menyatakan bahwa penerapan model pembelajaran kooperatif tipe Think Pair Share (TPS) dapat meningkatkan pemahaman, keterampilan berpikir ktitis, kinerja, dan motivasi siswa .

Menurut Nurhadi (2004), tujuan model Think Pair Share (TPS) secara umum adalah untuk meningkatkan penguasaan akademik dan mengajarkan keterampilan sosial. Selanjutnya, Trianto (2011), berpendapat bahwa Think Pair Share (TPS) adalah a) dapat meningkatkan kinerja siswa dalam tugas-tugas akademik, b) unggul dalam membantu siswa memahami konsep-konsep yang sulit, c) membantu siswa menumbuhkan kemampuan berpikir kritis. Berdasarkan pendapat tersebut dapat disimpulkan bahwa model TPS dapat meningkatkan hasil belajar Kognitif.

Model pembelajaran Kooperatif tipe Survey Question Read Recite Review $(S Q 3 R)$ adalah suatu model pembelajaran yang berpusat pada pembelajar (Student Center) karena siswa di tuntut berperan aktif dalam menggali dan memperkaya pemahaman mereka terhadap konsep konsep yang dipelajari, model ini juga memberikan kemungkinan kepada para siswa untuk belajar secara sistimatis, efektif dan efisien dalam menghadapi berbagai materi ajar (Wijaya, 2015). Lebih lanjut Nur dalam Pujawa (2005) menyatakan bahwa model pembelajaran Kooperatif tipe Survey Question Read Recite Review (SQ3R) lebih efisien dipergunakan untuk belajar karena siswa dapat belajar berulang-ulang mempelajari materi ajar berdasarkan langkah-langkah : (1) mereview bacaan atau materi ajar 
(Survey), (2) membuat pertanyaan pertanyaan tentang bacaan (question) (3), membaca/ mempelajari bacaan untuk mencari jawaban atas pertanyaan-pertanyaan yang telah di buat (read), (4) membacakan atau menuliskan kembali jawabanjawaban atas pertanyaan-pertanyaan yang mereka buat (recite) dan (5) meninjau ulang seluruh jawaban atas pertanyaan yang tersusun pada langkah kedua dan ketiga (review). Model pembelajaran kooperatif tipe Survey Question Read Recite Review (SQ3R) memiliki beberapa kelebihan, yaitu adanya tahap survey pada awal pembelajaran, hal ini membangkitkan rasa ingin tahu siswa tentang materi yang akan dipelajari dan meningkatkan hasil belajar siswa.

Perpaduan model pembelajaran TPSSQ3R dalam pembelajaran diharapkan memberi pengalaman belajar secara maksimal terhadap peserta didik. Hal ini disebabkan karena sintak TPS dapat meningkatkan hasil belajar peserta didik terlebih pada tahap think, sedangkan sintak $S Q 3 R$ selain pada sintak survey dapat membangkitkan rasa ingin tahu peserta didik juga pada tahap Question dan Read memaksa peserta didik membuat pertanyaan yang substansial dan menjawab pertanyaan sehingga dapat membangun struktur berpikir dan dapat meningkatkan hasil belajar peserta didik.

Sudjana (2009) menyebutkan bahwa yang memiliki peran penting terhadap proses belajar mengajar adalah hasil belajar. Hasil belajar adalah sebagai terjadinya perubahan tingkah laku pada diri seseorang yang dapat diamati dan diukur dalam bentuk pengetahuan, sikap dan keterampilan. Perubahan tersebut dapat diartikan sebagai terjadinya peningkatan dan pengembangan yang lebih baik dari sebelumnya dan yang tidak tahu menjadi tahu (Hamalik, 2007).

Penilaian hasil belajar dapat memberikan informasi kepada guru tentang kemajuan siswa dalam upaya mencapai tujuan belajar melalui berbagai kegiatan belajar mengajar. Menurut Aunurrahman (2012), hasil belajar dipengaruhi oleh pengalaman siswa tentang lingkungannya. Hasil belajar siswa tergantung dari apa yang dia ketahui baik berkenan dengan pengertian, konsep, formula dan sebagainya. Hasil belajar merupakan pola-pola perbuatan, nilai-nilai, pengertian-pengertian, sikap-sikap, apresiasi dan keterampilan (Suprijono, 2007).

Berdasarkan wawancara yang dilakukan dengan beberapa orang guru mata pelajaran IPA di SMP Negeri 6 kota Ternate sebagian besar melaksanakan pembelajaran secara konvensional. Hal tersebut dikarenakan guru beranggapan bahwa materi-materi IPA Terpadu lebih tepat disampaikan dengan metode ceramah, Metode yang digunakan oleh guru selain ceramah adalah diskusi dengan mempelajari sendiri materi, baik melalui buku atau internet. Diskusi yang 
dilaksanakan selama ini kurang efektif karena tidak semua peserta didik aktif dalam menyampaikan pendapat hanya beberapa peserta didik saja yang aktif dalam diskusi, sementara peserta didik yang lain cenderung pasif. Meskipun guru sudah menerapkan model pembelajaran berbasis kelompok,tetapi pembelajaran tersebut belum sepenuhnya terarah dan terkondisikan dengan baik oleh sebab itu diperlukan suatu model pembelajaran yang tepat yang dapat dijadikan solusi dalam memecahkan permasalahan pembelajaran IPA Terpadu dalam meningkatkan hasil belajar peserta didik di SMP Negeri 6 Kota Ternate.

Penelitian ini bertujuan untuk mengetahui perpaduan model Think Pair Share dengan Survey Question Read Recite Review dapat meningkatkan hasil belajar kognitif peserta didik Kelas IX di SMP Negeri 6 kota Ternate.

\section{METODE}

Metode Penelitian yang digunakan adalah eksperimen Semu ( Quasy eksperimen). Penelitian ini dilaksanakan di SMP Negeri 6 kota Ternate pada bulan Oktober sampai dengan bulan Desember 2018 dengan sampel pada penelitian ini berjumlah 64 peserta didik, kelas IX-6 Menggunakan model pembelajaran Think Pair Share (TPS), kelas IX-3 menggunakan model pembelajaran Survey Queation Read Recite Review sedangkan kelas IX-5 Menggunakan model perpaduan Think Pair Share dengan Survey Question Read Recite Review. Instrumen yang digunakan dalam penelitian ini adalah pre test dan post test, silabus, RPP serta Sintaks perpaduan model TPS dengan SQ3R disajikan pada tabel berikut.

Tabel 1 Sintaks Perpaduan Model Pembelajaran TPSSQ3R

\begin{tabular}{|c|l|l|}
\hline Fase & \multicolumn{1}{|c|}{ Kegiatan Guru } & \multicolumn{2}{|c|}{ Kegiatan Peserta Didik } \\
\hline $\begin{array}{c}\text { Fase 1 } \\
\text { Pendahuluan }\end{array}$ & $\begin{array}{l}\text { Guru menyampaikan Tujuan } \\
\text { pembelajaran dan memberi motivasi }\end{array}$ & $\begin{array}{l}\text { Peserta didik menyimak } \\
\text { penjelasan guru }\end{array}$ \\
\hline Fase 2 & $\begin{array}{l}\text { Peserta didik diminta untuk mengkaji } \\
\text { pustaka mengenai materi yang akan } \\
\text { dipelajari }\end{array}$ & $\begin{array}{l}\text { Peserta didik membaca } \\
\text { berbagai sumber terkait } \\
\text { materi yang telah disediakan } \\
\text { oleh guru }\end{array}$ \\
\hline Fase 3 & $\begin{array}{l}\text { Peserta didik diminta membentuk } \\
\text { kelompok secara berpasangan }\end{array}$ & $\begin{array}{l}\text { Peserta didik membentuk } \\
\text { kelompok } \\
\text { berpasangan }\end{array}$ \\
\hline Fase 4 & $\begin{array}{l}\text { Peserta didik diminta menyusun daftar } \\
\text { pertanyaan yang relevan dengan teks } \\
\text { materi pembelajaran }\end{array}$ & $\begin{array}{l}\text { Peserta didik menyusun } \\
\text { pertanyaan dari hasil bacaan }\end{array}$ \\
\hline Fase 5 & $\begin{array}{l}\text { Peserta didik diminta memberi jawaban } \\
\text { terhadap pertanyaan yang disusunnya }\end{array}$ & $\begin{array}{l}\text { Peserta didik melalukan } \\
\text { diskusi dengan pasanganya } \\
\text { mengenai jawaban atas } \\
\text { pertanyaan yang telah }\end{array}$ \\
\hline
\end{tabular}




\begin{tabular}{|c|c|c|}
\hline & & disusun \\
\hline Fase 6 & $\begin{array}{l}\text { Guru meminta pasangan tertentu untuk } \\
\text { melakukan presentase }\end{array}$ & $\begin{array}{lr}\text { Kelompok } & \text { pasangan yang } \\
\text { ditunjuk } & \text { melakukan } \\
\text { presentase } & \\
\end{array}$ \\
\hline Fase 7 & $\begin{array}{l}\text { Guru menanggapi hasil diskusi dan } \\
\text { meluruskan pemahaman peserta didik } \\
\text { mengenai materi,kemudian } \\
\text { bersama sama peserta didik } \\
\text { menyimpulkan materi yang telah } \\
\text { dipelajari }\end{array}$ & $\begin{array}{l}\text { Peserta didik menyimak dan } \\
\text { menarik kesimpulan }\end{array}$ \\
\hline Fase 8 & Guru mengevaluasi & $\begin{array}{l}\text { Peserta didik mengerjakan } \\
\text { soal-soal evaluasi }\end{array}$ \\
\hline
\end{tabular}

Materi yang digunakan dalam penelitian ini adalah reproduksi pada tumbuhan dan hewan. Penelitian ini merupakan eksperimen semu yang terdiri dari 3 kelas perlakuan yaitu, Kelas IX-6 perlakuan Model Pembelajaran Think Pair Share, Kelas IX-3 dengan perlakuan model Survey Question Read Recite Review dan Kelas IX-5 dengan perlakuan perpaduan model Think Pair Share dengan Survey Question Read Recite Review. Masing-masing kelas diberi tes Pretest secara tertulis. Penerapan model pembelajaran sesuai dengan perlakuan. Kemudian postest diberikan secara tertulis. Data hasil penelitian ini dianalisis menggunakan uji Anova. Syarat uji Anova adalah Homogenitas dan Normalitas hasil belajar, Analisis statistik Anova menggunakan program SPSS versi 22.0.

\section{HASIL DAN PEMBAHASAN}

\section{A. Hasil Penelitian}

Sebelum menganalisis data terlebih dahulu dilakukan uji prasyarat, analisis uji prasyarat menggunaan uji homogenitas dan uji normalitas, uji homogenitas bertujuan untuk menguji apakah setiap kelompok yang dijadikan objek penelitian untuk dibandingkan memiliki varian yang sama,sedangkan uji normalitas digunakan untuk mengetahui sebaran frekuensi skor tiap variabel terdistribusi normal atau tidak. Uji normalitas dilakukan dengan uji one-sample KolmogorovSmirnov melalui bantuan program SPSS for windows versi 22.0, jika data sudah normal dan homogen maka dilanjutkan dengan uji Hipotesis untuk mengetahui besar pengaruh model pembelajaran terhadapat hasil belajar. 


\section{Uji Homogenitas Hasil Belajar}

Berdasarkan perhitungan diperoleh signifikasi (P-level) lebih besar dari 0,05 (P.0,05), hal ini menunjukan bahwa H0 diterima. Jadi Varian antara kelompok data tidak berbeda atau homogen (Tabel 2)

Tabel 2 Hasil Uji Homogenitas Antar Varian dengan Hasil Belajar
\begin{tabular}{|c|c|c|c|c|}
\hline & Levene Statistic & df1 & df2 & Sig. \\
\hline Pretes & 1.530 & 2 & 61 & .225 \\
\hline Postes & 3.032 & 2 & 61 & .056 \\
\hline
\end{tabular}

Dari uji Homogenitas pada tabel 2 diperoleh signifikansi pretest yaitu 0.225 sedangakan pada postes dengan nilai signifikansi yaitu 0,56 dengan demikian nilai signifikansi > 0,05, menunjukan data tersebut adalah homogen.

\section{Uji Normalitas}

Data nilai Postest berdistribusi normal baik kelas kontrol maupun kelas eksperimen, hal ini dibuktikan dengan nilai signifikansi hasil uji KolmogorovSmirnov pada Tabel 3 dibawah ini .

Tabel 3. Hasil uji Kolmogorov-Smirnov

\begin{tabular}{|ll|r|r|}
\hline & & Pretes & \multicolumn{1}{|c|}{ Postes } \\
\hline Normal Parameters ${ }^{\mathrm{a}}$ & Mean & 64 & 64 \\
& Std. Deviation & 35.0156 & 76.7969 \\
& Absolute & 9.16427 & 5.07149 \\
Most Extreme & Positive & .141 & .141 \\
Differences & Negative & .141 & .108 \\
& & -.112 & -.141 \\
Kolmogorov-Smirnov Z & & 1.130 & 1.125 \\
Asymp. Sig. (2-tailed) & & .155 & .159 \\
\hline
\end{tabular}

3. Uji Hipotesis variabel hasil Belajar

Hasil uji statistik Anova pengaruh perlakuan hasil belajar pada tabel 4 dapat diinterprestasikan bahwa model pembelajaran menunjukan nilai signifikansi 0,000 $<0,05$ yang berarti hipotesis penelitian diterima dan hipotesis nol ditolak, dan 
menunjukan bahwa ada pengaruh model pembelajaran terhadap hasil belajar kognitif.

Tabel 4 Hasil uji anova pengaruh perlakuan terhadapa hasil belajar .

\begin{tabular}{|l|r|r|r|r|r|}
\hline Source & $\begin{array}{c}\text { Type III Sum of } \\
\text { Squares }\end{array}$ & df & Mean Square & F & \multicolumn{1}{c|}{ Sig. } \\
\hline Corrected Model & $450.749^{\mathrm{a}}$ & 3 & 150.250 & 7.708 & .000 \\
Intercept & 19447.289 & 1 & 19447.289 & 997.629 & .000 \\
Pretes & 208.326 & 1 & 208.326 & 10.687 & .002 \\
Model_Belajar & 192.820 & 2 & 96.410 & 4.946 & .010 \\
Error & 1169.611 & 60 & 19.494 & & \\
Total & 379077.000 & 64 & & & \\
Corrected Total & 1620.359 & 63 & & & \\
\hline
\end{tabular}

Berdasarkan hasil analisis menunjukan bahwa dengan perpaduan model pembelajaran Think Pair Share (TPS) dengan Survey Question Read Recite Review (SQ3R) ini dapat meningkatkan hasil belajar kognitif, hal tersebut dapat dilihat pada Tabel 5 berikut ini.

Tabel 5 Peningkatan rata rata hasil Belajar

\begin{tabular}{|l|r|r|r|}
\hline Model_Belajar & Mean & Std. Deviation & $\mathrm{N}$ \\
\hline TPS & 74.6000 & 5.69764 & 20 \\
SQ3R & 76.2727 & 4.43129 & 22 \\
TPS+SQ3R & 79.3182 & 4.07532 & 22 \\
Total & 76.7969 & 5.07149 & 64 \\
\hline
\end{tabular}

Tabel 5 menunjukkan bahwa Mean skor hasil belajar pada model TPS adalah sebesar 74,60, model pembelajaran $S Q 3 R$ adalah sebesar 76,27 dan perpaduan model TPS dengan $S Q 3 R$ mencapai 79,32.

Perpaduan model TPSSQ3R dapat meningkatkan hasil belajar. Peningkatan hasil belajar dapat dilihat dari tingginya nilai rerata posttest, hal tersebut disebabkan karena sintak perpaduan model pembelajaran TPSSQ3R dapat meningkatkan ketrampilan berpikir peserta didik terutama pada fase 4 dan 5 yaitu 
peserta didik diminta menyusun pertanyaan dari hasil kajian pustaka dan sekaligus mencari jawaban pertanyaan yang telah disusun. Model TPSSQ3R diharapkan efektif dalam meningkatkan hasil belajar, karena pada sintak model ini terdapat kegiatan menyusun pertanyaan, Hal ini sesuai dengan pendapat Brown dan Walton (1995) dalam Zusye (2009) bahwa menyusun pertanyaan memiliki 2 tahap kognitif yaitu tahap Accepting (menerima) dan tahap Challenging (menantang) terjadi pada saat pesrta didik menyusun pertanyaan, proses Accepting (menerima) memungkinkan peserta didik menempatkan suatu informasi pada suatu jaringan struktur kognitif, sedangkan proses kognitif Challenging (menantang) dapat memungkinkan jaringan yang ada pada diri peserta didik akan semakin kuat hubungannya (Marzuki 2005, dalam Zusye 2009).

Hasil uji hipotesis menunjukan bahwa ada pengaruh model pembelajaran terhadap hasil belajar kognitif peserta didik. Hal ini disebabkan kegiatan didalam sintak model TPSSQ3R dapat menjadikan peserta didik lebih aktif sehingga dapat meningkatkan hasil belajar. Belajar aktif merupakan langkah cepat, menyenangkan, mendukung dan menarik hati dalam belajar (Rusmaryanti. 2013). Guna mempelajari sesuatu dengan baik, belajar aktif membantu untuk mendengarkan, melihat, mengajukan pertanyaan tentang pelajaran tertentu dan mendiskusikannya dengan peserta didik yang lain. Senada dengan yang disampaikan oleh Hidayat (2001) upaya untuk meningkatkan keberhasilan pendidikan adalah menggunakan pembelajaran aktif dimana peserta didik melakukan sebagian besar kegiatan yang harus dilakukan. Belajar aktif mengacu pada pembelajaran kooperatif karena didalamnya akan terjadi interaksi sesama kelompok. Hasil belajar, menurut Arikunto (1990) adalah hasil yang dicapai seseorang setelah melaksanakan kegiatan belajar dan merupakan penilaian terhadap peserta didik untuk mengetahui sejauh mana bahan pelajaran atau materi yang diajarkan dapat dikuasai oleh peserta didik. Disamping sebagai indikator keberhasilan belajar juga dapat berguna sebagai evaluasi dalam proses pembelajaran.

Perpaduan model pembelajaran TPSSQ3R juga mengacu pada pendekatan Saintifik. karena model pembelajaran TPSSQ3R mencakup tiga strategi pemahaman yaitu (1) mengkaji pustaka dengan cara mengamati dan membaca, (2) menyusun pertanyaan, membangkitkan rasa ingin tahu, minat, dan perhatian peserta didik, mendorong dan menginspirasi peserta didik untuk aktif belajar serta mengembangkan pertanyaan dari dan untuk dirinya sendiri. (3) Mencari jawaban atas pertanyaan yang telah disusun peserta didik diajak untuk mengumpulkan 
pengetahuan sebanyak mungkin dari berbagai sumber (mengekplorasi). Perpaduan model TPSSQ3R dapat meningkatkan hasil belajar kognitif pada mata pelajaran IPA Terpadu karena membantu peserta didik dalam memahami sebuah bacaan. Hal ini juga disampaikan oleh Taro (2009) bahwa membaca akan memperluas wawasan, memperkaya perspektif, mempertajam pikiran dan perasaan, serta memperoleh bekal untuk mengarungi kehidupan yang sebenar benarnya. Dalam hal ini pembaca akan mempelajari informasi baru, ide utama bacaan, argument orang lain dan berusaha mengaitkannya dengan pengalaman sebelumnya.

\section{SIMPULAN}

Berdasarkan hasil dan pembahasan, dapat disimpulkan bahwa perpaduan model pembelajaran TPS dan $S Q 3 R$ dapat meningkatkan hasil belajar peserta didik. Hasil belajar peserta didik menggunakan perpaduan model pembelajaran Think Pair Share dengan Survey Question Read Recite Review rata-rata skornya 79,32, sedangkan rata-rata skor hasil belajar peserta didik dengan menggunakan model SQ3R 76,27 dan TPS sebesar 74,60. Pada pengujian Hipotesis menunjukan bahwa model pembelajaran memperoleh nilai signifikan $0,000<0,05$ (hipotesis diterima) yaitu hasil belajar peserta didik yang menggunakan perpaduan model Think Pair Share dengan Survey Question Read Recite Review lebih baik dari pada Think Pair Share maupun Survey Question Read Recite Review.

\section{DAFTAR PUSTAKA}

Agus Suprijono. 2007. Pemilihan Model-model pembelajaran dan penerapannya di SMP. Semarang: UNNES.

Arikunto Suharsimin. 1990. Dasar-Dasar Evaluasi pendidikan. Jakarta: Bumi Aksara.

Aunurrahman. 2012. Belajar dan pembelajaran. Bandung: Alfabeta.

Aunurrahman. 2013. Belajar dan pembelajaran. Bandung; Alfabeta.

Kitaoka, H. 2013. Teaching methods that help ekonomi students to be effective problem solves. International journal of arts andcommerce, 2 (1) : 101-110.

Komaruddin Hidayat. 2001. Active Learning. Yogjakarta: Yappendis.

Nana Sudjana. 2000. Dasar-dasar proses belajar-mengajar. Bandung. PT Sinar Baru Algensindo.

Nurhadi. 2004. Pembelajaran konstekstual (CTL) dan penerapannya dalam KBK. Malang, Universitas Negeri Malang.

Oemar Hamalik. 2007. Proses belajar mengajar. Jakarta Bumi aksara. 
Pamikatsih E. 2015. Pengaruh penggunaan strategi Think Pair Share (TPS) dengan strategi Survey Question Read Recite Review (SQ3R) terhadap hasil belajar siswa kelas IV SDN 02 Selokatan. Karanganyer.(online) diakses 05 Pebruari 2019.

Purwanto. 2010. Evaluasi hasil belajar. Yogyakarta, Pustaka Belajar.

Pujawa, I Gusti Ngurah. 2005. Penerapan model pembelajaran kooperatif dengan metode SQ3R dalam meningkatkan aktifitas dan prestasi belajar matematika siswa SMP. Jurnal pendidikan, dan pengajaran, IKIP negeri Singaraja no 5 Tahun XXXVIII, Juli 2015.

Rusmayanti, D. 2013. Meningkatkan hasil belajar biologi dengan model pembelajaran kooperatif tipe TPS pada siswa kelasa VIII MTS Alhuda 2 Jenewi karang anyar Tahun Pelajaran tahun pelajarn 2012/2013. Jurnal pendidikan, 22 (3).

Sujana, N. 2009. Dasar-dasar proses belajar mengajar. Bandung: Sinar Baru Algensindo.

Taro, M. 2009. Gemarlah membaca, maka cerdaslah bangsaku. Dalam Bali Post 27 Desember 2009, Hal 17 Kolom 3-7.

Trianto. 2011. Model Pembelajaran terpadu. Jakarta: Bumi Aksara.

Wasit. 2011. Upaya meningkatkan kualitas pembelajaran konsep dasar IPA tentang Tata Surya dengan penerapan model SQ3R siswa kelas V SD Negeri 2 Kebumen.

Widyantini. 2008. Penerapan pembelajaran kooperatif Tipe STAD dalam pembelajaran matematika SMP. Yogyakarta, Pusat pengembangan dan pemberdayaan pendidik dan tenaga kependidikan matematika.

Wijaya, Ratih Ayu, dkk. 2015. Penerapan model Survey Question Read Recita Review (SQ3R) dalam pembelajaran IPA SMP. Jurnal Pendidikan Fisika IKIP, Universitas Jember.

Zanah, Nanik Choirul. 2006. Penerapan metode think pair share (TPS) dalam pembelajaran kooperatif untuk meningkatkan aktivitas dan hasil belajar akuntansi keuangan siswa kelas I B-AK di SMK Salahuddin Malang (online) diakses 12 Januari 2019.

Zusye, Strategic management for education management, Bandung, alfabeta. 